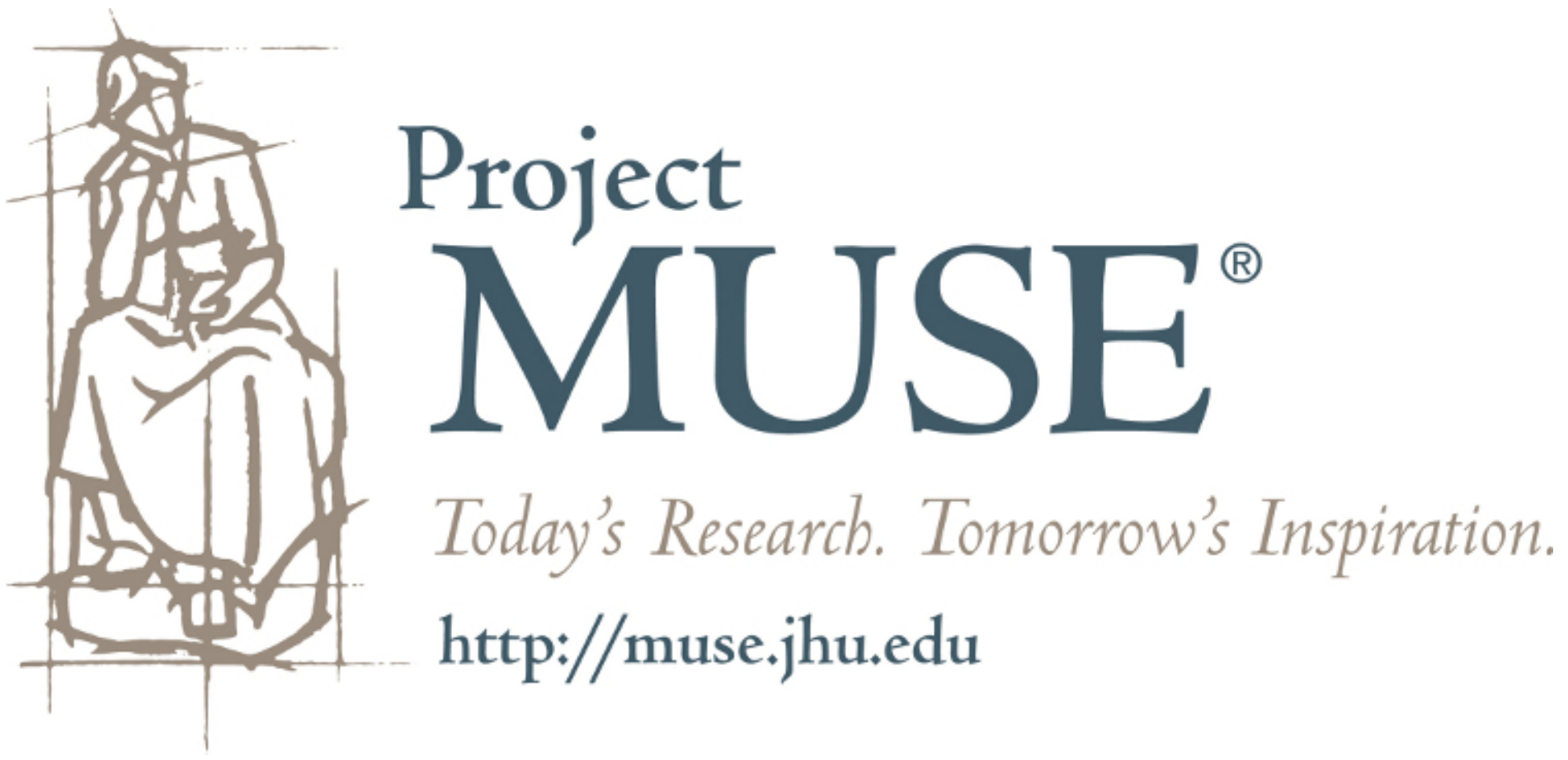




\section{DeAF EPISTEMologies as a CRITIQUe AND Alternative to the Practice of Science: An Anthropological Perspective}

Goedele A. M. De Clerck

DE CLERCK IS A POSTDOCTORAL SCHOLAR, Department of Comparative Science of Culture, Ghent University, BELgIUm.

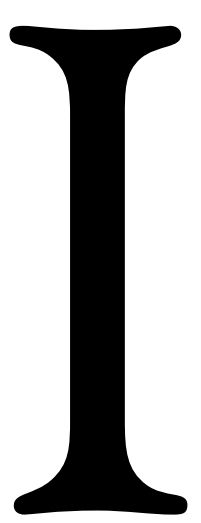

N THE LAST DECADE, and responding to the criticism of orientalism, anthropology has engaged in a self-critical practice, working toward a postcolonial perspective on science and an epistemological stance of partial and situated knowledge (Pinxten, 2006; Pinxten \& Note, 2005). In deaf studies, anthropological and sociological studies employing qualitative and ethnographic methods have introduced a paradigm shift. Concepts of deaf culture and deaf identity have been employed as political tools, contributing to the emancipation process of deaf people. However, recent anthropological studies in diverse local contexts indicate the cultural construction of these notions. From this viewpoint, deaf studies faces a challenge to reflect on the notions of culture, emancipation, and education from a nonexclusive, noncolonial perspective. Deaf studies research in a global context needs to deal with cultural and linguistic diversity in human beings and academia. This calls for epistemological reflection and new research methods.

Recently, young deaf academics in Flanders (myself included) who have received training in deaf studies abroad have criticized standard views in research proposals related to the Flemish deaf community. ${ }^{1}$ Deaf scholars have expressed concern about hypotheses and research methods that do not take into account the unique and diverse cultural and social life of members of the deaf community, and have argued for the inclusion of deaf scholars in research projects. An additional political dimension is the lack of research opportunities for young deaf people in Flanders. Although the concept of deaf epistemologies has not been explicitly discussed, deaf studies actually has evolved into a line of thought that is taken for granted by young deaf people who specialized in deaf studies. However, the Flemish case also illustrates that deaf epistemologies are not (yet) common sense in science.

Conceptualizing and continuing this discussion from an epistemic stance involves raising questions such as these: Is there a deaf way of viewing the world? What is the status of (indigenous) deaf knowledge(s) versus science? How can deaf knowers be conceptualized in science? In what context are science and knowledge 
produced, and what is the value of science? How do deaf people construct their knowledge? Is it legitimate for deaf people to claim knowledge, and why?

To date, no books have been published with titles such as Introduction to Deaf Epistemologies or Deaf Critique and Science. The purpose of the present article is to offer insight into the notion of deaf epistemologies. ${ }^{2}$ Drawing on the field of anthropology, which has inspired and legitimated the cultural turn in deaf studies, and situating deaf epistemologies in the evolution of the philosophy of science, I argue for the feasibility of the notion of deaf epistemologies as an alternative line of cognition and theorizing in an approach to science that is sensitive to and inclusive of gender, class, race, culture, and disability.

Deaf epistemologies challenge scholars and others to reflect on audism and phonocentrism in the production of theory and knowledge, and are driven by a desire to have eyes for the hands that sign deaf perspective(s) on social reality. This deaf criticism goes hand in hand with a radical stance toward science that can be found in Marxist criticism, postcolonial and subaltern criticism, feminist criticism, and Black/Afrocentric criticism, among other disciplines, and that provides the basis for critical discussion of the social and cultural structure of knowledge production and the influence of epistemic theorizing on daily life (e.g., Aldridge \& James, 2007; Ashcroft, Griffiths, \& Tiffin, 1995; Collins, 1990; Tanesini, 1999; Tyson, 1999). As a young and interdisciplinary field, deaf studies has also heavily relied on these disciplines. Deaf epistemologies are emancipation oriented, and motivated by the wish of deaf people to live equal lives and to live up to their potential.

Although the emergence of the concept of deaf culture led to a deaf cultural critique on science, it was not until recently that epistemological issues were explicitly addressed in deaf studies. Further meta-theorizing can contribute significantly to the development of its critical project. In the present article, I aim to contribute to this project by providing a culturesensitive alternative in deaf studies, exemplified in a discussion of globallocal dynamics in deaf identity, deaf culture, and deaf education.

\section{Anthropology and the Development of a Noncolonial Science}

For a broader anthropological and epistemological stance, I draw on Pinxten (2006) and Pinxten and Note (2005), though additional sources are also employed. In a personal history, Geertz (1995) reflected on the shifts and confusion in anthropology after the decolonization of the world. The field could no longer maintain its confidence in the objectivity of science to project a mirror for humankind. The postcolonial critique of orientalism (Ashcroft et al., 1995; Said, 1995) challenged the universality and objectivity of science. Debating the culturalladenness of theories (Nader, 2006), and wondering whether local views are equally as valid as the Western one, anthropology has evolved toward being a self-critical discipline.

Pinxten (2006) argues that both the positivist and the phenomenological approaches in anthropology and the social sciences are guilty of a colonial attitude: Research subjects are reduced to objects, and indigenous knowledge of the informants is granted secondary status in the production of scientific knowledge about indigenous knowledge. Research involves a double-bias situation (both the researcher and the research subjects are biased). Since the quality of the empirical data is cru- cial in anthropology, the quality of the interaction that researchers participate in is decisive for theory development. An epistemological stance of bidirectionality is called for to overcome the colonialist attitude: Research is a contextualized interactive and communicative process between the researchers and collaborators, who participate in a joint venture of negotiation and control of different stages in the research process and results (see also Pinxten, 1997b). Bourdieu's praxeology and Fabian's performance ethnography are examples of research methodologies that are in line with this approach and are developed during fieldwork.

Bourdieu's praxeology (Bourdieu, 1990, 1998; Bourdieu \& Wacquant, 1992) moves beyond the opposition between objectivism and subjectivism, analyzing both objective structures and the observational and attitudinal categories of agents. This epistemological stance grants equal roles to the researchers and collaborators in the study: The researcher shares his or her observations and interpretations, and the participants reflect on the researcher's process of knowledge construction. This dialectical process continues until both parties agree that the knowledge produced is valid and significant. Fabian's (1990) performance ethnography moves away from informative ethnography to an approach in which the ethnographer fits in a "realistic praxis" (p. 18) and gains insight through experiencing, doing, and learning. Cultural knowledge is created and transmitted in and through events in a coproduction of anthropologists and informants, who guide the anthropologist as far as he or she is granted access.

It can be argued that the debate on the status of indigenous knowledge 3 versus science has been settled (Pinxten, 2006; see also Nader, 2006; Pottier, 
Bicker, \& Sillitoe, 2003; Sillitoe, 1998). On the one hand, there is the research on ethnoscience (e.g., Pinxten, 1997a, 1997b) indicating that indigenous thought systems use cognitive tools that were supposed to be reserved for Western thought; on the other hand, some styles of everyday thought are close to scientific thinking (Crombie, 1994).

In a globalized world, interaction between people from diverse backgrounds has increased. Anthropological research has revealed a slow and gradual transformation and hybridization of cultures (Appadurai, 2003; Hannerz, 2003; Young, 1995). Parallel to the third industrial revolution of information technology and against the background of marginalization of groups who are not able to follow technological progress, a mobilization of local, regional, cultural, and religious identities can be noticed (Massey \& Jess, 1995; Pinxten \& De Munter, 2006). As an international and human practice, science needs to deal with researchers from a variety of local contexts, as well as with diversity in human beings. If the countermovement of postcolonial studies is taken into account, an open and nonexclusive view of science is highly relevant (Pinxten, 2006; Pinxten \& Note, 2005).

\section{Deaf Epistemologies and Alternatives to the Practice of Science}

Situating the notion of deaf epistemologies in the philosophy of science, in this section of the present article I sketch developments that paved the way for critiques such as the radical and the feminist (see also Duran, 1998, Tanesini, 1999). For discussion on the structure and nature of scientific theories, and the debate between the received view of positivism and the weltanschauungen views, I draw on Suppe (1977). According to the received view, science is a cumulative enterprise oriented toward finding a true theory that is the key to nature. The received view claims epistemic foundationalism in its efforts toward a logic of justification: Each scientific theory can be (re)formulated by rules of correspondence between the language of theory and the language of observation. The observer is distinguished from the object of observation: Any interference by the subject is eliminated, and theories are confirmed by empirical verification. This leads to a deductive certainty as far as is possible at that moment in time.

According to the criticism that came to the fore in the 1950s and 1960s, science is conducted from within a weltanschauung. Hence, epistemological theorizing must pay attention to the dynamic historical and sociological context and the linguisticconceptual frameworks that influence the production of science and knowledge. Kuhn's (1962) analysis points out the value of the notion of a consensus or shared research tradition (paradigm) that is the basis for scientific theorizing among the researchers working in the same field. Hanson (1958) analyzed the example of the astronomers Johannes Kepler and Tycho Brahe watching the sun rise and holding different theories, respectively, of the earth moving so that the sun could be observed, and of the sun revolving around the earth. The question is whether Kepler and Brahe actually did see the same thing. Hanson argued that seeing is shaped by knowledge, which pleads for a logic of discovery. Observation is theory laden: Knowledge is reasonable for a particular subject in a particular context, while the meaning of reasonable depends on the conceptual and theoretical framework that influences the organization of the data. Feyerabend (1965) criticized science's neutral observation language and the dogmatic radical empiricism of the received view. He acknowledged the need for theoretical pluralism. Suppe (1977) concluded that the analyses provided by the alternative philosophies of science were vague and otherwise inadequate. However, he further observed, the motivation for the construction of these alternatives was to be found in the weaknesses of positivism.

Important for the discussion of deaf epistemologies is that the alternative and diverse philosophies of the various weltanschauungen not only share their critical stance toward the received view but reflect on the social construction of scientific practice. In the present article, I explore lines of thought developed in deaf studies rather than provide a complete analysis or overview of deaf epistemologies.

\section{Deaf Epistemologies as a Critique and Alternative to the Practice of Science}

In 1965, Stokoe, Casterline, and Croneberg's Dictionary of American Sign Language on Linguistic Principles presented groundbreaking linguistic research at Gallaudet College and legitimized ASL as a bona fide language. Drawing on the fields of structural comparative linguistics and anthropology, and published in a period of social activism in the United States, the dictionary used a new vocabulary to describe the language and the lives of deaf people (Padden, 1980; Padden \& Humphries, 2005).

"The Linguistic Community," an appendix to A Dictionary of American Sign Language on Linguistic Principles (Stokoe et al., 1965), provides academic recognition and a description of "the social and cultural characteristics of the linguistic community" (p. 297). The text employs notions such as minority group, community, and culture. About a decade earlier, in a 
pioneering study on the social life of the deaf, Lunde (1956) had proposed to view deaf people as a "subculture" in The Sociology of the Deaf, which influenced Stokoe (1960).

This new perspective on deaf people as a cultural and linguistic minority group led to a paradigm shift in the field of deaf studies in the decades that followed: Sociological and anthropological studies (e.g., C. Erting, 1978; Higgins, 1980; Padden \& Humphries, 1988; Woodward, 1982) employing qualitative and ethnographic research methods documented the lives of deaf people from an emic perspective. A deaf knowing subject emerged, and deaf ways of seeing and being were claimed.

Woodward (1982) conceptualized this focus, distinguishing between deaf, referring to the hearing status of deaf people (and how deaf people are viewed by hearing people) and Deaf, referring to the perspective of deaf people who view themselves as a group with a language and a culture. (It is important to note that the deaf/Deaf distinction cannot be readily made in some languages, for example, Japanese; see Nakamura, 2005.)

Preparing to write a book on the lived experiences of members of the American deaf community, Padden and Humphries (1988) noticed that deaf people's daily lives, values, myths, and art had escaped the focus of science. In their book, Deaf in America: Voices From a Culture, Padden and Humphries not only aimed to throw a light on deaf culture from the inside; they also aimed to employ a deaf way of writing, 4 "in contrast to the long history of writing that treats [deaf people] as medical cases, or as people with 'disabilities,' who 'compensate' for their deafness by using sign language” (p. 1).

Padden and Humphries (2005, p.

2) subsequently drew on the work of
George Veditz, who had described deaf people as "first, last, and for all time, people of the eye" in 1912, to emphasize that although the notion of culture may be new, deaf people have always viewed themselves as visually oriented, and, as such, have developed knowledge about themselves and the world:

Deaf people's practices of "seeing" are not necessarily natural or logical, in the sense that they have a heightened visual sense, but their ways of "seeing" follow from a long history of interacting with the world in certain ways-in cultural ways. (p. 2)

On Depathologizing Deafness, the subtitle of a series of papers published by Woodward between 1975 and 1979 (and issued in book form in 1982 under the main title How You Gonna Get to Heaven if You Can't Talk With Jesus), implies a critique of the practice of science. Not only had the experiences of deaf people been excluded from science (see also Higgins, 1980), but the epistemic foundationalism of science had been put into question: Science was perceived as a practice that was not value neutral, but instead influenced by hearing ideology. Markowicz and Woodward (1982) noticed that the literature on deafness was dominated by psychological studies that investigated the causal relationship between deaf people's behavior and intelligence while failing to take into account the possible influence of the deaf cultural experience in the testing situation. Markowicz and Woodward also questioned the results of research on deaf community membership done by hearing researchers who were not members of the deaf community.

This line of criticism has been expanded in a postmodern stance in deaf studies. Drawing on the work of Michel Foucault, Lane (1999) compared the oppression of deaf people and the colonization of the deaf body with the colonization of Africa. On an intellectual level, he distinguished two kinds of discourse: a cultural perspective and an infirmity-based perspective. On a pragmatic level, Lane wrote, power and money are in play. He referred to Humphries's notion of audism: "In short, audism is the hearing way of dominating, restructuring, and exercising authority over the Deaf community" (p. 43).

Lane (2005) deconstructed social science research as an institution that objectifies and paternalizes deaf people. He also criticized the relationship between research and technology: The economic benefits of what Foucault called "bio-power," Lane wrote, are exemplified by the promotion of the cochlear implant. Genetic research is another example of Foucault's normalization technologies that are threatening the deaf world.

\section{The Emancipatory Value of the Deaf Culture Notion}

Connected with deaf studies' criticism on science described in the previous paragraph is deaf epistemologies' concern with the emancipatory value of science. Initial anthropological and sociological studies have explored and employed terms such as Deaf culture and Deaf identity as political tools that could contribute to the emancipation process of deaf people (Padden \& Humphries, 2005). In 2005, looking back on the writing of their first book, in 1988, and the first use of the term culture to describe the lives of deaf people, Padden and Humphries stated that they were "writing not as anthropologists but as agents of a changing discourse and consciousness" (p. 2). Deaf people 
were still reluctant to have their language be examined and be public; debates with anthropologists concerned the question of whether deaf culture was a bona fide culture. Rather taxonomic descriptions and a search for definitions of deaf culture, deaf community, membership, and etbnicity mark this stage of research that is primarily concerned with the scientific legitimization of deaf culture and advocacy on behalf of the deaf cause (e.g., C. Erting, 1978; Johnson \& C. Erting, 1989; Kyle, 1990; Padden, 1980; Woodward, 1982).

A discussion in the journal Sign Language Studies in 1994 touched on epistemological perspectives in deaf studies. Turner (1994) questioned the circularity of definition seeking in the field of deaf studies to that point, the homogeneous and static construction of the deaf culture concept, and the political motivation underlying the research studies aiming to document a distinct deaf culture. In critiques of his paper, researchers argued that deaf culture was originally an academic term that had been adopted by deaf people (Bahan, 1994; Stokoe, 1994). It was also argued that the use of categories developed by deaf people (e.g., $D E A F-W O R L D)$ should be encouraged, and differences between terms should be critically examined (Andersson, 1994; Bahan, 1994). Recognizing the value of anthropological frameworks to the emancipation of deaf people (Monaghan, 1994), scholars called for critical reflection on the limits of general frameworks for understanding deaf culture. Johnston (1994) drew on the social sciences to legitimate deaf scholars' explicit support of the deaf cause: Criteria such as transparency on the position and motivation of the researcher were to be regarded as more appropriate than a standard notion of objectivity. The scholars agreed that diversity in the deaf community should be explored. Bahan (1994, p. 248) suggested that "it may be productive to investigate how Deaf people see what unites and divides us."

This inward turn was developed by Ladd (2003). Dissatisfied with the medical term deafness, he conceptualized a deaf way of being and knowing in the epistemic notion of "Deafhood." Deafhood is based on the experience of signing deaf people who were born deaf or were deafened at an early age. Deafhood

represents a process-the struggle by each Deaf child, Deaf family, and Deaf adult to explain to themselves and each other their own existence in the world. In sharing their lives with each other as a community ... Deaf people are engaged in a daily praxis, a continuing internal and external dialogue. (p. 3)

Providing a strong center, "which can then create new spaces for more sophisticated liberatory discourses to flourish" (Ladd, 2003, p. 81), the concept of Deafhood is necessarily strategically essentialist, a stance based on Spivak's subaltern theory (e.g., Spivak, 1995). Deafhood is expressed in the global connections of deaf people and shared deaf experience and sign language use. Deafhood allows for diverse readings.

\section{A Global Perspective and Cultural Critique in Deaf Studies}

Documenting diversity, studies have analyzed the intertwining of axes of differences in the lives of deaf women (e.g., Brueggeman \& Burch, 2006), Black deaf people (e.g., Williamsen, 2002), deaf gay and lesbian people (e.g., Breivik, 2005), and other deaf minorities. A partial, situated deaf experience can stimulate deaf people to reflect on their own perspectives, learn different views, and support each other in a "politics of empowerment" (Collins, 1990, p. 188).

In the following paragraphs I discuss studies on the lives of deaf people in non-Western countries and on deaf people moving between different cultural contexts, with the objective of deepening a cross-cultural and comparative perspective in deaf studies (see Andersson, 1981, 1990, 1991). ${ }^{5}$

In an interplay between changes in local sociocultural, political, and educational contexts and the distribution of emancipatory discourses, linguistic research has fostered the legitimization of sign languages and consciousness-raising in deaf communities worldwide (Baker \& Battison, 1980; C. Erting, Johnson, Smith, \& Snider, 1994; Goodstein, 2006; Monaghan, Schmaling, Nakamura, \& Turner, 2003). Monaghan (2003) distinguished some common patterns in deaf communities, which have emerged anytime deaf people have interacted. This has been the case in urban places where deaf people can gather (e.g., Lane, 1984), and in places with a high rate of deafness (e.g., Johnson, 1994). The founding of deaf schools in Europe and the United States in the 19th century enabled deaf children to acquire sign language in interaction with deaf peers. Deaf schools have been considered root places of deaf culture; deaf adults have socialized in deaf clubs, often founded close to these schools (Fisher \& Lane, 2003; Van Cleve \& Crouch, 1989).

Deaf schools in developing countries were often established through the efforts of missionaries under colonial influences or under the auspices of programs to develop cooperation 
between countries. Consequently, schools adopted the philosophy and sign language of the founding or supporting country (Barcham, 1998; C. Erting et al., 1994; Goodstein, 2006). A general internationalism has fostered a growing recognition of deaf people's rights and has been beneficial to deaf people's empowerment (Monaghan et al., 2003).

These social developments have influenced deaf people's lives and identity construction. Deaf studies research and the emancipation movement of ethnic minorities and their discourses transformed deaf identities in the United States. Deaf people liberated themselves from medical discourses and identified as members of a linguistic and cultural minority group (Jankowski, 1997). A research review of literature on the dynamics of deaf identity in northwestern Europe (De Clerck, in press-b) indicates a three-stage model of emancipation. In the first stage, deaf people come under the influence of oralism, are subordinated, and withdraw from society. In the second stage, the legitimization of sign language through linguistic research politicizes deaf identities, with deaf people claiming a separate linguistic and cultural identity after the 1970s. In the third stage, young deaf people who have grown up in inclusive realms of life view sign language as a regular mode of communication; being deaf is an aspect of diversity in a pluralistic society. Although a political basis is maintained, the boundary between the hearing and deaf communities has weakened. Simultaneously, studies reveal that deaf people easily communicate transnationally, adapting their own sign language, using international sign, or picking up the local sign language. Benefiting from globalization and from technological and economic resources, some young deaf people develop transnational deaf identities (e.g., Breivik, 2005; De Clerck, 2007; Haualand, Gronningsaeter, \& Hansen, 2003; Turner, 2004).

Apart from these trends, it is important to note that the construction of deaf identity is also related to local sociocultural, political, educational, and social policy constructions, and hence differs among countries. The politicization of deaf identity and the emancipation processes in deaf communities should also be interpreted against the background of historical and anthropological research that finds that deaf people are included in social life in some contexts (e.g., Groce, 1995; Johnson, 1994). This observation raises the question of whether unitary concepts such as deaf culture and deaf identity can be used to gain accurate insight into culturally constructed deaf identities.

Insight into the cultural construction of deaf identities is particularly relevant to understanding conflicts between and shifts in identities in a transnational and global context. Deaf people's transnational interaction has fostered the transfer of (culturally constructed) discourses on deaf identity, sign language, and deaf culture, and has raised deaf consciousness (Breivik, 2005; De Clerck, 2007; Le Master, 2003; Nakamura, 2005).

Nakamura's (2005) anthropological research in Japan reveals how conflicts have emerged between a younger generation of deaf people who are inspired by presentations of American deaf activists and identify as culturally deaf, and a senior generation of deaf people who also define themselves as culturally deaf, yet without a capital D and in an otherwise different way. The older group of deaf people attended deaf schools and have continued to socialize in deaf organizations since graduation. Voicing while signing, they view sign language as a mode of com- munication that does not fundamentally differ from Japanese. The younger generation experienced linguistic and social exclusion in mainstreaming. Influenced by American discourses on deaf identity and deaf culture, they developed political deaf identities and advocate a pure sign language. Nakamura warns that in a homogeneous Japan, ethnolinguistic discourses will not easily receive government recognition, whereas deaf people have been able to receive recognition as a disability group.

Between 1984 and 1988 and again in 2000, LeMaster (2003) did ethnographic research in the deaf community in Dublin, Ireland. Her study in linguistic anthropology found shifts in identity between a senior generation of deaf people who grew up in a signing educational environment and a younger generation of deaf people who did not experience educational inclusion. The older generation conceptualizes sign language as a regular mode of communication and is open to including hearing people in conversations. Enforced oralism has led to "oppositional Deaf identities" in young deaf people (Le Master, 2003, p. 168) and the adoption of cultural and political deaf discourses. Le Master noted the transfer of deaf cultural discourses through transnational (European) contacts and exchanges with Gallaudet University. The differences between the two generations of deaf people have not led to a political separation. Few of the older people participate in ethnic-minority discourses. However, they have supported the political organization and promotion of Irish Sign Language led by the younger group.

I studied emancipation processes through the life stories of 25 international deaf people at Gallaudet University (De Clerck, in press-a). Applying a multidimensional and multilayered 
analytical framework that conceptualizes identity dynamics as a complex of processes (Pinxten, Verstraete, \& Longman, 2004), I gained insight into differences and conflicts in culturally situated constructions of deaf identity. Deaf people are exploring different ways to negotiate toward equal status for sign language and deaf people in local contexts. In my research (De Clerck, in press-a), I deconstructed one-dimensional and monolithic concepts of deaf identity and deaf culture, which are often employed in the field of deaf studies, as culturally situated (and Western) perspectives. If this theoretical operation is to be more fully developed and insight is to be gained into identity dynamics and processes of empowerment in deaf people and deaf communities in different localities, cross-cultural comparative research will be necessary. In-depth understanding of culturally constructed identity dynamics can contribute significantly to successful contextualized intercultural negotiation (De Clerck, in press-a; see also Pinxten, 1999) of core constructs that are vital to deaf people.

To achieve this goal, the anthropological methods described in the present article under the heading "Anthropology and the Development of a Noncolonial Science" may be employed in the field of deaf studies as well. For a comparative perspective, Geertz's (1983) empirical study and cultural description of fact and law in different local contexts is inspiring. Those methods are valuable for deaf researchers as well, who share cultural intuitions with the people who collaborate in the research. ${ }^{6}$

\section{Deaf Education}

The paradigm shift in deaf studies goes hand in hand with deaf-centered and bilingual-bicultural education that provides deaf students with the opportunity to learn sign language and deaf culture, come into contact with deaf role models and teachers, and become equipped with the knowledge and skills to negotiate core constructs in their identity and live equal lives. The question "Whose education?" (Simms, 2006) illustrates deaf people's claims to involvement in all aspects of deaf education.

Consistent with the anthropological framework of the present article, research methods and expertise from the field of ethnoscience (e.g., Pinxten, $1997 \mathrm{a}, 1997 \mathrm{~b}$ ) may be valuable to deaf education. Education, cognition, and learning processes are socioculturally specific phenomena; therefore, it is important to develop concepts and terms within the vernacular language, categorization system, and learning strategies. The studies exploring visual learning strategies are in line with this research orientation. In a long-term interdisciplinary ethnographic study, C. Erting, Bailes, L. Erting, Thumann-Prezioso, and Kuntze (2006) investigated the development of ASL/English literacy-learning strategies of deaf children in both the home and classroom environments. The interaction of the children with their deaf teachers, compared with the interaction with their deaf and hearing (sign language-learning) parents, reveals a rich variety in deaf knowledge. Another example is the research documenting how deaf parents and teachers mediate English in bilingual settings, moving back and forth among ASL, fingerspelling, and written English (C. Erting, ThumannPrezioso, \& Benedict, 2000; Padden, 1996a, 1996b).

In a study on deaf empowerment in Flemish deaf role models (De Clerck, 2007), I found that empowered deaf peers and barrier-free environments in the United Kingdom, the United States, and the Nordic countries provided examples of possible and inspiring ways of living in comparison with the Flemish context. Global deaf identities, a common use of sign language, and the experience of being deaf facilitate the transfer of empowering knowledge. The concept deaf ways of education was employed to refer to this informal networking and emancipatory information exchange among deaf people. C. Erting (1996, p. xxiii), writing on "the Deaf way," said, "For as long as Deaf people have formed communities, a Deaf way of life has been recognized by Deaf people themselves. These patterns of behavior, attitudes, beliefs, and values have been referred to in American Sign Language as 'DEAF TEND (THEIRS)."' Reilly (1995) used the phrase "deaf way of education" in the title of his doctoral dissertation (A Deaf Way of Education: Interaction Among Children in a Thai Boarding School), and explained about visual modes of learning and communication among deaf students.

Western educational programs for deaf students in non-Western countries and education programs for deaf immigrant children that fail to take into account indigenous (deaf) knowledge $(s)^{7}$ may cause cultural and linguistic transformations, disruptions, and oppression. Anthropological studies call for a critical perspective.

Branson and Miller's (2004) study of the linguistic environment in northern Bali illustrates how education programs inspired by Western experts and concepts can be examples of neocolonialism. Deaf children from an inclusive signing environment are instructed in a national language (Indonesian) and sign language (i.e., a signed system) that is not used in their local environment. This is not only ineffective, but also results in semilingualism and in poor communication when deaf students return home. They may have lost their ability 
to speechread the Balinese language and communicate with non-Indonesian-speaking relatives; only strong signing environments provided by family members who have not lost their signing competence during their children's education guarantee appropriate communication. This situation challenges the deaf community concept, which originated in the development of Western deaf communities around deaf schools. The question is which community's sign language should be implemented in education: "The only communities of relevance to the deaf students in the schools are communities where local languages are spoken and where the signing used is thoroughly localized" (Branson \& Miller, p. 32).

In Kano State, Nigeria, Schmaling's (2003) ethnographic research found that the local inclusion of deaf people and wide use of sign language as a mode of communication by both hearing and deaf people is threatened by urbanization and by the implementation of ASL in education, which suggests that the local sign language is inferior. This divides the deaf community into educated deaf people using ASL, on the one hand, and uneducated deaf people and hearing people using indigenous sign language, on the other hand.

A study by Branson and Miller (1998) on the education of deaf immigrant children in Australia indicated that the concept of bilingual-bicultural education can be exclusive if it does not include indigenous languages and indigenous sign languages. Branson and Miller proposed an educational plan for deaf students of non-Englishspeaking and non-Australian Sign Language-using backgrounds to graduate as bilingual in two sign languages and two written sign languages at the end of secondary education.
Storbeck and Magongwa (2006) have developed a fruitful approach to a diverse deaf studies curriculum that can meet the needs of a heterogeneous deaf community. As exemplified in the learning situation of deaf Zulu children in South Africa, the scholars have employed the multiethnic educational framework of Banks (1994) to integrate deaf culture into the whole school and curriculum while paying attention to the mixed backgrounds of deaf children, "thus creating a Deaf-centric curriculum-including content, visual learning and teaching styles, and Deaf indigenous teaching and learning practices" (Storbeck \& Magongwa, p. 121).

While similarities in deaf epistemologies suggest global learning strategies of visually oriented and signing people, sensitivity to different ways of indigenous deaf learning and the broader context in which this learning takes place is crucial. Successful education for deaf students necessarily involves multilingualism and an understanding of culturally situated meanings of education and emancipation.

\section{Conclusion}

The place to test the success of an educational system is not in the schoolroom nor in conversation over the social teacup, but out where men toil and earn their daily bread. (Schuyler Long, cited in Crammate \& Friedman, 1941, p. 407, cited in Andersson, 1991, p. 99)

Parallel with and drawing upon minority critiques, deaf epistemologies have put the value-neutrality and objectification in science into question. The diverse lives and experiences of deaf people should be the methodological basis for research. Criticizing audism and phonocentrism in the practice of science, deaf epistemologies have looked at old problems from a different angle and contributed to a more appropriate science (see also Nader, 2006). I argue for multiple perspectives in the evaluation of research (see also Campbell, 1989), and a reflexive stance on dynamics of (linguistic and cultural) power relations in the academy (Bourdieu, 1990, 1998).

Deaf studies has become institutionalized predominantly in Western countries, and, as anthropological and sociological studies indicate, a critical perspective is needed toward cultural bias in notions of deaf identity, deaf culture, deaf empowerment, and deaf education as employed in deaf studies.

Deaf scholars, in particular scholars from deaf minorities, are still underrepresented in the field; their scholarship should be encouraged. Developing different lines in metatheorization is vital to the future of deaf studies and the lives of deaf people. Joint intercultural and interdisciplinary research projects between deaf and hearing scholars will foster methodological reflection and exploration.

A democratic, pluralistic society should encourage individuals and groups to (acquire the power to) live according to their own views. (Organizations of) deaf people should be able to organize education according to their own solutions (Andersson, 1991). These include multilingualism (Reagan \& Osborn, 2002; SkutnabbKangas, 2008) and, as the present article illustrates, multiple deaf epistemologies. In a diverse world with equal languages, cultures, and human beings (Skutnabb-Kangas, 1990), multiple literacies change standard views on reading achievement in favor of a focusing on and 
valuing of deaf people's contextualized and sign language literacy (Brueggeman, 1995, 2004), and a notion of education that looks further than the classroom to include (indigenous) deaf ways of learning (e.g., De Clerck, 2007).

While recognizing that different factors may explain the educational failure of deaf students documented in research, I point out that true bilingual education for deaf students in ideal conditions crucial to successful bilingual education is still scarce (SkutnabbKangas, 1990, 2008). To provide deaf people with the best circumstances and chances to live up to their potential, diverse forms of knowledge, scientific and indigenous, may be needed (see also Nader, 2006). The wisdom and experiences deaf people have gained from life may be the best source for evaluating efforts toward this end.

\section{Author's Note}

I give special thanks to Dr. Donald Moores and Dr. Peter Paul. I also thank Dr. Yerker Andersson and Dr. Rik Pinxten for providing feedback on drafts of this paper. Correspondence concerning the present article should be addressed to Goedele De Clerck, Palingstraat 61, 2870 Puurs, Belgium. E-mail: Goedele.DeClerck@UGent.be

\section{Endnotes}

1. In the present article, a d/D distinction is not made. This usage decision draws on Breivik, Haualand, and Solvang (2002, p. v), who, reflecting on the (confusing) application of this distinction, quoted Fjord (1996, p. 66), who described it as "in a constant stage of flux within the deaf community." The present article focuses on diversity in deaf cultural lives; questions on the d/D distinction are illustrative of tension between a standpoint line and a culturally sensitive stance (see further in the present article), and should be discussed in future papers.

2. In writing the present article, I have relied on the literature on feminist epistemologies (e.g., Code, 2006; Collins, 1990; Davis, Evans, \& Lorber, 2006; Duran, 1998; Tanesini, 1999). Feminist theorizing has evolved across a large number of publications, representing a rich and diverse range of views. Consequently, I am not able to able to cover all the theoretical issues; an extensive analytical discussion of parallels and differences between feminist and deaf epistemologies would be an interesting research topic for another paper. Code (2006) points out that meta-theorizing was put on the feminist agenda rather late. Theories often refer to Sandra Harding's (1980) distinction of three epistemological strands in feminist theorizing: feminist empiricism, feminist standpoint theories, and feminist postmodernism. Harding's classification has been criticized: Distinctions among these lines of inquiry cannot always be clearly drawn, theories cannot always be classified as such, and researchers often employ more than one line of thought at the same time. Recognizing this criticism and being cautious to apply the classification to the field of deaf studies at this early stage, I think the classification is useful for acquiring insight into deaf epistemologies, and that the three lines of inquiry might provide inspiration for further meta-theorizing in the field of deaf studies.

3. I am aware that terms such as indigenous knowledge and local knowledge have different denotations and connotations (see also Sillitoe, 1998). However, in-depth discussion is beyond the scope of the present article.

4. Studies have expanded this line of thought, for example, in the exploration of visual rhetoric, ASL literacy/signacy, and the cinematographic characteristics of sign language (e.g., Brueggeman, 1995, 2004; Paul, 2006).

5. Although I do follow Andersson's comparative perspective, I disagree on the positivistic orientation of cross-cultural comparative research in Andersson (1981). Instead, in line with the work of Pinxten (1997b; 2006), I argue for in-depth empirical, situated, cultural comparison in line with Geertz (1983; see further in the present article).

From my comparative perspective, I have been inspired by having deep conversations and living daily life with international deaf friends during my 3-year stay at Gallaudet University. The emancipation of deaf people in our home countries throughout the world was our prior concern, and a favorite topic of discussion and reflection. I consider the strong international bond and solidarity among deaf people and our use of sign language to be one of the most vital aspects of my life. However-and this experience has been confirmed in my encounters with deaf people during travel on different continents-I think it is crucial to recognize differences. For example, I did not grow up in a country that takes bilingual-bicultural education for deaf people for granted; nor was I born in sub-Saharan Africa, unable to marry because my boyfriend lacked educational opportunities and was unemployed.

6. Reflecting on the position of deaf researchers, Ladd (2003) argued that the notion of insider does not take into account the academic background of deaf researchers and other differences with grassroots deaf people such as growing up mainstreamed and having English as a first language. Drawing upon subaltern studies, Ladd 
developed the notion of "subaltern elite researcher."

Another valuable perspective that I have found useful in explaining differences related to the academic training of deaf researchers and other differences in background is Collins's (1990) concept of "outsider-within," which refers to the position of people who belong to a community but occupy a relatively marginal position. Although a complete description of my own position in research studies is beyond the scope of the present article, I would like to note that-depending on the people I collaborated with and the context of the study-apart from factors mentioned by Ladd (education and mainstreaming), I experienced age and gender as differentiating categories, as well as my cultural (European/White) background. Deaf researchers may relate to the experience of Black women in academia who "remain outsiders within, individuals whose marginality provides a different angle of vision on the theories put forth by ... intellectual communities" (Collins, 1991, p. 12, cited in Tanesini, 1999, p. 152).

7. In the present article, I use the term deaf knowledge (s) to refer to deaf people's ways of knowing. I noticed that C. Erting and colleagues (2006) covered this meaning with the term "Deaf indigenous knowledge"; however, in the present article, the term deaf indigenous knowledge(s) refers to non-Western deaf knowledges. The term "Deaf indigenous knowledge" in Storbeck and Magongwa (2006) may include both meanings - this was not clear to me.

\section{References}

Aldridge, D. P., \& James, E. L. (Eds.). (2007). Africana studies: Philosophical perspectives and theoretical paradigms. Pullman, WA: Washington State University Press.

Andersson, Y. (1981). A cross-cultural comparative study: Deafness. Unpublished doctoral dissertation, University of Maryland, College Park.

Andersson, Y. (1990). The Deaf world as a linguistic minority. In S. Prillwitz \& T. Vollhaber (Eds.), Sign language research and application (pp. 155-161). Hamburg, Germany: Signum.

Andersson, Y. (1991, March). Some sociological implications of Deaf studies. A paper presented at the National Deaf Studies Conference, Dallas, TX.

Andersson, Y. (1994). Comment on Turner. Sign Language Studies, 83, 127-131.

Appadurai, A. (2003). Modernity at large: Cultural dimensions of globalization. Minneapolis: University of Minnesota Press.

Ashcroft, B., Griffiths, G., \& Tiffin, H. (Eds.). (1995). The postcolonial studies reader. New York: Routledge.

Bahan, B. (1994). Comment on Turner: View from the Deaf world. Sign Language Studies, 83, 241-249.

Baker, C., \& Battison, R. (Eds.). (1980). Sign language and the Deaf community. Silver Spring, MD: National Association of the Deaf.

Banks, J. A. (1994). Multiethnic education: Theory and practice (3rd ed.). Boston: Allyn \& Bacon.

Barcham, L. (1998). The international dimension. In S. Gregory, P. Knight, W. McCracken, S. Powers, \& L. Watson (Eds.), Issues in deaf education (pp. 245-254). London: David Fulton.

Bauman, D. (2008). Listening to phonocentrism with Deaf eyes: Derrida's mute philosophy of (sign) language. Essays in Philosophy: A Biannual Journal, 9(1). Retrieved July 24, 2008, from http://www.humboldt.edu/ essays/bauman.html

Bourdieu, P. (1990). The logic of practice. Cambridge, England: Polity Press.

Bourdieu, P. (1998). Practical reason. Cambridge, England: Polity Press.

Bourdieu, P., \& Wacquant, L. (1992). An invitation to reflexive sociology. Cambridge, England: Polity Press.

Branson, M., \& Miller, D. (1998). Achieving human rights: Educating deaf immigrant students from non-English-speaking families in Australia. In A. Weisel (Ed.), Issues unresolved: New perspectives on language and deaf education (pp. 88-100). Washington, DC: Gallaudet University Press.

Branson, M., \& Miller, D. (2004). The cultural construction of linguistic incompetence through schooling: Deaf education and the transformation of the linguistic environment in Bali, Indonesia. Sign Language Studies, 5, 6-38.

Breivik, J. (2005). Deaf identities in the making: Local lives, transnational connections. Washington, DC: Gallaudet University Press. Breivik, J., Haualand, H., \& Solvang, P. (2002). Rome - a temporary deaf city! Deafly- mpics 2001 (Working Paper No. 2-2003). Bergen, Norway: Stein Rokken Center for Deaf Studies, University of Bergen. Retrieved October 12, 2005, from http://www .ub.uib.no/elpub/rookkan/N/N02-02.pdf

Brueggeman, B. (1995). The coming out of Deaf culture and American Sign Language: An exploration into visual rhetoric and literacy. Rhetoric Review, 13(2), 409-420.

Brueggeman, B. (Ed.). (2004). Literacy and deaf people: Cultural and contextual perspectives. Washington, DC: Gallaudet University Press.

Brueggeman, B., \& Burch, S. (2006). (Eds.) Women and deafness: Double visions. Washington, DC: Gallaudet University Press.

Campbell, D. (1989). Methodology and epistemology for social sciences. Chicago: University of Chicago Press.

Code, L. (2006). Women knowing/knowing women: Critical-creative interventions in the politics of knowledge. In K. Davis, M. Evans, \& J. Lorber (Eds.), Handbook of gender and women's studies (pp. 146-167). Thousand Oaks, CA: Sage.

Collins, P. H. (1990). Black feminist thought: Knowledge, consciousness, and the politics of empowerment. London: The Women's Press.

Crombie, A. (1994). Styles of scientific thinking in the European tradition. London: Redwood Books.

Davis, K., Evans, M., \& Lorber, J. (2006). Handbook of gender and women's studies. Thousand Oaks, CA: Sage.

De Clerck, G. (2007). Meeting global deaf peers and visiting ideal deaf places: Deaf ways of education leading to empowerment, an exploratory case study. American Annals of the Deaf, 152(4), 5-15.

De Clerck, G. (in press-a). Searching for negotiation space and tools: Translated deaf people moving towards emancipation. Medische Antropologie.

De Clerck, G. (in press-b). Identiteitsdynamieken in Vlaamse dove rolmodellen: Een verkenning van tendenzen in emancipatieprocessen in dovengemeenschappen en parallellen met etnische minderheden in Europa [Identity dynamics in Flemish deaf role models: An exploration of trends in emancipation processes in deaf communities and parallels with ethnic minorities in Europe]. Volkskunde.

Duran, J. (1998). Philosophies of sciencelfeminist theories. Boulder, CO: Westview Press.

Erting, C. (1996). Introduction. In C. Erting, R. C. Johnson, D. L. Smith, \& B. D. Snider (Eds.), The Deaf way: Perspectives from the International Conference on Deaf Culture (pp. xxiii-xxxi). Washington, DC: Gallaudet University Press.

Erting, C. (1978). Language policy and Deaf eth- 
nicity in the United States. Sign Language Studies, 19, 139-152.

Erting, C., Bailes, C., Erting, L., ThumannPrezioso, C., \& Kuntze, M. (2006). Signs of literacy: Naturalistic inquiry into ASL/English bilingualism at home and at school. In $\mathrm{H}$. Goodstein, (Ed.), The Deaf Way II reader: Perspectives from the Second International Conference on Deaf Culture (pp. 88-99). Washington, DC: Gallaudet University Press.

Erting, C., Johnson, R. C., Smith, D. L., \& Snider, B. D. (Eds.). (1994). The Deaf way: Perspectives from the International Conference on Deaf culture. Washington, DC: Gallaudet University Press.

Erting, C., Thumann-Prezioso, C., \& Benedict, B. (2000). Bilingualism in a deaf family. In P. Spencer, C. Erting, \& M. Marschark, (Eds.), The deaf child in the family and at school (pp. 41-54). Mahway, NJ: Erlbaum.

Fabian, J. (1990). Power and performance: Ethnographic explorations through proverbial wisdom and theater in Shaba, Zaire. Madison: University of Wisconsin Press.

Feyerabend, P. (1965). Problems of empiricism. In R. Colodny, (Ed.), Beyond the edge of certainty (pp. 145-260). Englewood Cliffs, NJ: Prentice Hall.

Fisher, R., \& Lane, H. (Eds.). (2003). Looking back: A reader on the history of Deaf communities and their sign languages. Hamburg, Germany: Signum.

Geertz, C. (1983). Local knowledge: Further essays in interpretive anthropology. New York: Basic Books.

Geertz, C. (1995). After the fact: Two countries, four decades, one anthropologist. Cambridge, MA: Harvard University Press.

Goodstein, H. (2006). The Deaf Way II reader: Perspectives from the Second International Conference on Deaf Culture. Washington, DC: Gallaudet University Press.

Groce, N. E. (1995). Everyone here spoke sign language: Hereditary deafness on Martha's Vineyard. Cambridge, MA: Harvard University Press.

Hannerz, U. (2003). Macro-scenarios: Anthropology and the debate over contemporary and future worlds. Social Anthropology, 11, 169-187.

Hanson, N. R. (1958). Patterns of discovery. Cambridge, England: Cambridge University Press.

Harding, S. (1980). The science question in feminism. Ithaca, NY: Cornell University Press.

Haualand, H., Gronningsaeter, A., \& Hansen, I. (2003). Uniting divided worlds: Identity, family, and education in the life projects of deaf and hard of hearing young people. Disability Studies Quarterly, 23, 75-88.

Higgins, P. (1980). Outsiders in a bearing world: A sociology of deafness. Beverly Hills, CA: Sage.

Jankowski, K. A. (1997). Deaf empowerment
Emergence, struggle, and rhetoric. Washington, DC: Gallaudet University Press.

Johnson, R. E. (1994). Sign language and the concept of deafness in a traditional Yucatec Mayan village. In C. Erting, R. C. Johnson, D. L. Smith, \& B. D. Snider (Eds.), The Deaf way: Perspectives from the International Conference on Deaf Culture (pp. 102-109). Washington, DC: Gallaudet University Press.

Johnson, R. E., \& Erting, C. (1989). Ethnicity and socialization in a classroom for deaf children. In C. Lucas, \& C. Valli (Eds.), Sociolinguistics of the Deaf community (pp. 41-83). San Diego, CA: Academic Press.

Johnston, T. (1994). Comment on Turner. Sign Language Studies, 83, 133-138.

Kuhn, T. S. (1962). The structure of scientific revolutions. Chicago: University of Chicago Press.

Kyle, J. (1990). The Deaf community: Culture, custom, and tradition. In S. Prillwitz \& T. Vollhaber (Eds.), Sign language research and application (pp. 175-185). Hamburg, Germany: Signum.

Ladd, P. (2003). Understanding Deaf culture: In search of Deafhood. Clevedon, England: Multilingual Matters.

Lane, H. (1984). When the mind hears. New York: Random House.

Lane, H. (1999). The mask of benevolence: Disabling the Deaf community. San Diego, CA: DawnSign Press.

Lane, H. (2005). Ethnicity, ethics, and the Deafworld. Journal of Deaf Studies and Deaf Education, 10(3), 291-301.

Le Master, B. (2003). School language and shifts in Irish Deaf identity. In L. Monaghan, C. Schmaling, K. Nakamura, \& G. Turner (Eds.), Many ways to be deaf: International variation in Deaf communities (pp. 153-172). Washington, DC: Gallaudet University Press.

Markowicz, H., \& Woodward, J. (1982). Language and the maintenance of ethnic boundaries in the Deaf community. In J. Woodward (Ed.), How you gonna get to heaven if you can't talk with Jesus: On depathologizing deafness (pp. 3-10). Silver Spring, MD: T. J. Publishers.

Massey, D., \& Jess, P. (Eds.). (1995). A place in the world: Places, cultures, and globalization. New York: Oxford University Press.

Monaghan, L. (1994). Comment on Turner. Sign Language Studies, 83, 139-144.

Monaghan, L. (2003). A world's-eye view: Deaf cultures in a global perspective. In L. Monaghan, C. Schmaling, K. Nakamura, \& G. Turner (Eds.), Many ways to be deaf: International variation in Deaf communities (pp. 1-24). Washington, DC: Gallaudet University Press.

Monaghan, L., Schmaling, C., Nakamura, K., \& Turner, G. (Eds.). (2003). Many ways to be deaf: International variation in Deaf com- munities. Washington, DC: Gallaudet University Press.

Nader, L. (2006). Naked science: Anthropological inquiry into boundaries, power, and knowledge. London: Routledge.

Nakamura, K. (2005). Deaf in Japan: Signing and the politics of identity. Ithaca, NY: Cornell University Press.

Padden, C. (1980). The Deaf community and the culture of deaf people. In C. Baker \& R. Battison (Eds.), Sign language and the Deaf community (pp. 89-103). Silver Spring, MD: National Association of the Deaf.

Padden, C. (1996a). Early bilingual lives of deaf children. In I. Parasnis (Ed.), Cultural and language diversity and the Deaf experience (pp. 99-116). New York: Cambridge University Press.

Padden, C. (1996b). From the cultural to the bicultural: The modern Deaf community. In I. Parasnis (Ed.), Cultural and language diversity and the Deaf experience (pp. 79-97). New York: Cambridge University Press

Padden, C., \& Humphries, T. (1988). Deaf in America: Voices from a culture. Cambridge, MA: Harvard University Press.

Padden, C., \& Humphries, T. (2005). Inside Deaf culture. Cambridge, MA: Harvard University Press.

Paul, P. (2006). New literacies, multiple literacies, unlimited literacies: What now, what next, where to? A response to blue Listerine, parochialism, and ASL literacy. Journal of Deaf Studies and Deaf Education, 11(3), 382-387.

Pinxten, R. (1997a). Application in the teaching of mathematics and the sciences. In A. Powel \& M. Frankenstein (Eds.), Ethnomathematics: Challenging Eurocentrism in mathematics education (pp. 373-401). Albany: State University of New York Press.

Pinxten, R. (1997b). When the day breaks: Essays in anthropology and philosophy. Frankfurt, Germany: Peter Lang.

Pinxten, R. (1999). Culturen sterven langzaam: Over interculturele communicatie [Cultures die slowly: On intercultural communication]. Antwerp, Belgium: Houtekiet.

Pinxten, R. (2006, September). The relevance of a noncolonial view on science and knowledge for an open perspective on the world. Paper presented at the biennial conference of the European Association of Social Anthropologists, Bristol, England.

Pinxten, R., \& De Munter, K. (2006). De culturele eeuw [The cultural century]. Antwerp, Belgium: Houteket.

Pinxten, R., \& Note, N. (2005). A naturalistic and critical view of social sciences and the humanities. In D. Aerts, B. D'Hooge, \& N. Note (Eds.), Worldviews, science, and us: Redemarcating knowledge and its social and ethical implications (pp. 93-103). Hackensack, NJ: World Scientific. 
Pinxten, R., Verstraete, G., \& Longman, C. (Eds.). (2004). Culture and politics: Identity and conflict in a multicultural world. New York: Berghahn Books.

Pottier, J., Bicker, A., \& Sillitoe, P. (Eds.). (2003). Negotiating local knowledge: Power and identity in development. Sterling, VA: Pluto Press.

Reagan, T., \& Osborn, T. (2002). The foreignlanguage educator in society: Toward a critical pedagogy. Mahway, NJ: Erlbaum.

Reilly, C. B. (1995). A Deaf way of education: Interaction among children in a Thai boarding school. Unpublished doctoral dissertation, University of Maryland, College Park.

Said, E. (1995). Orientalism: Western conceptions of the Orient. London: Penguin Books.

Schmaling, C. (2003). A for apple: The impact of Western education and ASL on the Deaf community in Kano State, Northern Nigeria. In L. Monaghan, C. Schmaling, K. Nakamura, \& G. Turner (Eds.), Many ways to be deaf: International variation in Deaf communities (pp. 302-310). Washington, DC: Gallaudet University Press.

Sillitoe, P. (1998). The development of indigenous knowledge: A new applied anthropology. Current Anthropology, 39(2), 223-252.

Simms, L. (2006). Deaf education: Whose "way" is it? In H. Goodstein (Ed.), The Deaf Way II reader. Perspectives from the Second Inter- national Conference on Deaf Culture (pp. 81-86). Washington, DC: Gallaudet University Press.

Skutnabb-Kangas, T. (1990). Language, literacy, and minorities. London: Minority Rights Group.

Skutnabb-Kangas, T. (2008, October). Linguistic buman rights of the deaf: Why, when, and what-and decided by whom? The little matter of crimes against humanity. Paper presented at the Gallaudet University Forum on Linguistic Human Rights and the Future of Sign Languages, Washington, DC.

Spivak, G. (1995). Can the subaltern speak? In B. Ashcroft, G. Griffiths, \& H. Tiffin (Eds.), The postcolonial studies reader (pp. 24-28). New York: Routledge.

Stokoe, W. C. (1960). Sign language structure: An outline of the visual communication systems of the American deaf. Buffalo, NY: University of Buffalo.

Stokoe, W. C. (1994). Comment on Turner. Sign Language Studies, 84, 265-270.

Stokoe, W. C., Casterline, D. C., \& Croneberg, C. G. (1965). A dictionary of American Sign Language on linguistic principles. Washington, DC: Gallaudet College Press.

Storbeck, C., \& Magongwa, I. (2006). Teaching about Deaf culture. In D. Moores \& D. S. Martin (Eds.), Deaf learners: Developments in curriculum and instruction (pp.
113-126). Washington, DC: Gallaudet University Press.

Suppe, F. (1977). The structure of scientific the ories. Urbana: University of Illinois Press.

Tanesini, A. (1999). An introduction to feminist epistemologies. Oxford, England: Blackwell.

Turner, G. (1994). How is Deaf culture? Another perspective on a fundamental concept. Sign Language Studies, 83, 103-121.

Turner, G. (2004). Exploring British experiences of language and Deafhood in hypermodernity. In M. Van Herreweghe \& M. Vermeerbergen (Eds.), To the lexicon and beyond: Sociolinguistics in European Deaf communities (pp. 248-263). Washington, DC: Gallaudet University Press.

Tyson, L. (1999). Critical theory today. New York: Garland.

Van Cleve, J. V., \& Crouch, B. A. (1989). A place of their own: Creating the Deaf community in America. Washington, DC: Gallaudet University Press.

Williamsen, C. E. (2002). Black deaf students: A model for educational success. Washington, DC: Gallaudet University Press.

Woodward, J. (Ed.). (1982). How you gonna get to heaven if you can't talk with Jesus: On depathologizing deafness. Silver Spring, MD: T. J. Publishers.

Young, R. (1995). Colonial desire: Hybridity in theory, culture, and race. New York: Routledge. 